DOI: 10.17805/ggz.2017.6.9

\title{
Пьесы У. Шекспира в советском театре и кинематографе (по материалам «Шекспировских чтений»). Часть І. Концепция «ренессансного» Шекспира
}

\author{
А. И. Кузьмичев
}

Институт научной информаџии по общественным наукам РАН, г. Москва

В ичкле статей анализируется советский стиль воплощения шекспировских пьес на сиене и в кино (постановки в Малом Театре и МХАТе, фильмы Г. М. Козинцева и т. д.) и его отличия от реконструкции прижизненных постановок драматурга, посмертных английских адаптачий и русского дореволючионного стиля. Автор показывает, что корни советской шекспировской эстетики лежат в общеевропейской традиции позднего романтизма и реализма, а также прослеживает, как именно она сформировалась.

В первой части рассматривается развитие концепџии "ренессансного» Шекспира на отечественной театральной сиене в дореволючионные годы и ее влияние на первые советские шекспировские постановки.

Ключевые слова: У. Шекспир; Шекспир в России; Шекспир в СССР; советский театр; "ренессансный» Шекспир; Шекспировские чтения; Мальй театр; МХАТ; Вс. Э. Мейерхольд; «Театральный Октябрь»; К. С. Станиславский

\section{W. Shakespeare's Plays in Soviet Theater and Cinematography (Adapted from the Proceedings of the "Shakespeare Readings"). Part I. The Concept of "Renaissance" Shakespeare}

A. I. Kuzmichev

Institute of Scientific Information on Social Sciences, Russian Academy of

Sciences, Moscow

The series of articles analyzes the Soviet style of presentation of Shakespeare's plays on stage and screen (productions at the Maly Theater and the Moscow Art Theatre, Grigori M. Kozintsev's films, etc.) and its differences from the reconstruction of stagings of Shakespeare's lifetime, posthumous English adapta-

\footnotetext{
Статья подготовлена в рамках проекта «Шекспир в современной русской культуре: национальное и глобальное», осуществляемого при поддержке Совета по грантам Президента РФ (МК-1182.2017.6).

The article was prepared within the framework of the project "Shakespeare in Contemporary Russian Culture: The National and Global” with support from the Council for Grants of the President of Russian Federation (MK-1182.2017.6).
} 
tions and the Russian pre-revolutionary style. The author shows that the roots of the Soviet Shakespearean aesthetics lay in the pan-European tradition of the late Romanticism and Realism and traces the stages of its development.

The first part examines the development of the concept of "Renaissance" Shakespeare on Russian stage in the pre-revolutionary years and its influence on the first Soviet Shakespearean theater productions.

Keywords: W. Shakespeare; Shakespeare in Russia; Shakespeare in the USSR; Soviet theater; "Renaissance" Shakespeare; Shakespeare Readings; Maly Theater; Moscow Art Theatre; Vselovod Meyerhold; "Theatrical October"; Konstantin Stanislavsky

\section{ВВЕДЕНИЕ}

Каждая культурная эпоха создает свой образ шекспировского театра, и советский период здесь не исключение. Однако социополитические обстоятельства требовали от молодого, возникшего революционным путем государства разрыва с предшествующей культурной и исторической традицией, отказом от прямой преемственности со «старым» миром, что не могло ни отразиться и на представлении об Уильяме Шекспире и его пьесах. Цель исследования - проанализировать сложившееся своеобразие советского периода отечественной шекспировской сцены, опираясь не только на работы советских шекспироведов, но и на театроведческие исследования и рецепцию известных актеров советских театров, ведь, как верно показал в своих работах известный театровед и исследователь творчества Шекспира А. В. Бартошевич, «литературоведческого исследования Шекспира недостаточно, для более точных выводов необходимо привлечь арсенал театроведческого исследования» (Захаров, Луков, 2009-: Электронный ресурс).

\section{ТЕАТРАЛЬНЫЙ ОКТЯБРЬ}

В современных отечественных гуманитарных науках не принято подробно останавливаться на роли Октябрьской революции в искусстве (что вполне объяснимо: у многих исследователей возникла стойкая аллергия на ритуальные ссылки на сочинения К. Маркса и Ф. Энгельса, обязательное использование диалектического материализма, прославление социалистического реализма как наиболее совершенной художественной формы и т. д. и т. п.), однако нельзя не сказать несколько слов о «завоеваниях Октября» в сфере искусства советской России.

Многие деятели искусства в России восприняли революцию как возможность осуществить свои самые смелые творческие планы, переформатировать всю культурную парадигму страны. В их числе был и известный театральный режиссер Вс. Э. Мейерхольд (1874-1940), соавтор «Театрального 
Октября» (1920) - радикальной программы по реформированию театра, опиравшейся на революционную эстетику современности. «Театральный Октябрь» провозглашал необходимость революционного переворота в театральном искусстве аналогичного октябрьскому. Его авторы призывали пересмотреть достижения, накопленные за всю историю мирового театра. По их мнению, новый театр должен быть политизированным, максимально быстро реагировать на текущие события, привлекать широкие слои населения посредством использования форм площадного театра для создания спектаклей, которые выступали бы рупором новых революционных идей (см.: Марков, 1967: стб. 159). И хотя программа оказалась короткоживущей (ее главные плоды - спектакли «Зори» (1920) и «Мистерия-буфф» (1921)), она оказала серьезное влияние на эстетику межвоенного советского театра.

В мире «Театрального Октября» Шекспиру, каким его ранее знал зритель, не было места. Идеологи направления были рады упомянуть его в своих статьях и выступлениях в числе прочих «великих», с удовольствием признавали преемственность с его эстетикой и техникой шекспировского театра ${ }^{1}$, когда им было это выгодно, но в действительности они отвергали и презирали его как слишком буржуазного, устаревшего автора. Характерно, что такие чувства испытывали не только отечественные участники программы «Театрального Октября», но и иностранные властители дум. Так, описывая английский театральный репертуар начала $20-\mathrm{x}$ гг. XX в. английский журналист и переводчик Эрик Верней (Eric Verney) писал: «Конечно, буржуазные театры ставят и классические пьесы, вроде Шекспира, исторические драмы и

1 Например, в будущем известный советский литературовед и театральный критик С. С. Мокульский обнаруживал преемственные связи между У. Шекспиром и Вс. Э. Мейерхольдом как в части сходства их творческой биографии («...в своем собственном лице Мейерхольд возродил тот тип режиссера-драматурга, который был свойствен всем подлинно театральным эпохам (вспомним Эсхила, Софокла, Плавта, Ганса Закса, Лопе де-Руэду, Шекспира, Мольера, Гольдони, Лессинга, Гете и мн. др.)» (Мокульский, 1926: 22)), так и в создаваемой Мейерхольдом эстетике конструктивистского театра: «Идею конструктивного оформления спектакля подсказало Мейерхольду изучение шекспировского театра с его расчлененной в горизонтальном и вертикальном направлении площадкой, и хронологически первая у Мейерхольда конструкция - станок “Великодушного рогоносца" - представляет собою ничто иное, как закономерное развитие форм шекспировской сцены (просцениум, балкон, заднее углубление). Но и эта трехмерная установка показалась недостаточно динамичной для современности, и вот в “Земле дыбом" вводится другой прием традиционных театров - пользование подвижными площадками (здесь - движущаяся трибуна), которые мы встречаем и в античном театре (эккиклема), и к средневековых мистериальных постановках (английские pageants), и в карнавальных празднествах итальянского Ренессанса (колесницы с размещенными на них аллегорическими персонажами). Впервые намеченный в “Земле дыбом”, этот прием далее эволюционирует и порождает сначала движущиеся стень в “Д. Е.”, а затем и движущиеся mpoтуары "Мандата" (курсив Мокульского. - A. K.), которые окончательно разрушают неподвижность ренессансной сцены-коробки» (там же: 23-24). 
даже более или менее “передовые", интеллигентские пьесы, но эти произведения проникнуты обычно идеологией средних классов или же слишком “высоким полетом”, чтобы быть понятными и оцененными рядовым, простым рабочим» (Верней, 1926: 121). А, например, немецкий историк литературы и театра Вильгельм Герцог (Wilhelm Herzog; 1884-1960), говоря о настроении публики, отмечал, что «свет хочет быть запутанным. Значит, давайте его запутывать. Не нужно только никакой логики. Вы требуете здравого смысла и обоснования человеческих поступков! Vieux jeu! Это умели уже делать Шекспир, Бальзак и Гоголь. Это смехотворное предписание старого, давно отдающего гнилью поколения» (Герцог, 1926: 135). Эти настроения во многом разделялись советским зрителем.

Театральная публика 1920-х гг., с одной стороны, отказывала в своем внимании спектаклям, сделанным в дореволюционной эстетике, требовала «нового» Шекспира, а с другой, - была не готова к экспериментам постановщиков, не желала синтеза Шекспира и «конструктивизма», в то время являвшегося наиболее авангардным театральным стилем. В результате постановщики шекспировских пьес оказались дезориентированы. Спектакли получались невнятные; зрители как будто ловили Шекспира прямо во время эстетической трансформации: отжитое уже воспринималось таковым и отбрасывалось, но новое еще не успело до конца возникнуть и занять положенное ему место.

В этом смысле характерна постановка «Юлия Цезаря», премьера которой состоялась в Малом театре 11 апреля 1924 г. (реж. И. С. Платон (18701935) $)^{2}$. Советские театроведы Л. С. Ходорковская и А. П. Клинчин пишут, что «все участники спектакля придавали ему большое значение, подходили с чувством высокой ответственности к воплощению на сцене грандиозного исторического полотна Шекспира, до революции запрещенного для постановки в императорских театрах» (Ходорковская, Клинчин, 1959: 343-344), но при этом отмечают, что «спектакль в целом никак не удовлетворил ни довольно холодно встретивших его зрителей, ни прессу, ни самих артистов Малого театра» (там же: 344). Театральный критик, присутствовавший на спектакле, писал в статье «“Юлий Цезарь” в Малом театре», опубликованной в № 85 газеты «Вечерняя Москва» от 11 апреля 1924 г.: «Ни настроений заговора, ни недоумений народа перед телом Цезаря, ни приятия речи Брута, ни гнева к Бруту в момент речи Антония - нет на сцене, но и героев событий также нет на сцене... Все те, кто видел “Юлия Цезаря” в Московском Художественном театре, все те, кто читал “Юлия Цезаря" в любом издании произведений

\footnotetext{
${ }^{2}$ Оформлением спектакля занимался художник Е. Е. Лансере. Роли исполняли: Юлий Цезарь - М. Ф. Ленин, Марк Антоний - А. А. Остужев, Брут - П. М. Садовский, Кассий - С. В. Айдаров, Порция - В. Н. Пашенная, Кальпурния - А. А. Яблочкина.
} 
Шекспира, тем более те, кто никогда не видел “Цезаря” или никогда не читал эту трагедию Шекспира, вряд ли могли что-либо понять. Совершенно невозможно сказать, кто из актеров Малого театра играл хуже в этом спектакле...» (цит. по: Ходорковская, Клинчин, 1959: 344).

Помимо слабости режиссуры театральная критика 1920-х гг., а вместе с ней и многие советские литературоведы и театроведы видят основную причину провала в том, что платоновская трактовка пьесы оказалась укорененной в традиции, в классической, буржуазной интерпретации, по которой Брут — предатель и убийца, а Марк Антоний — верный друг и соратник великого лидера, что не отвечало требованиям момента. Раннесоветские критики, а вместе с ними и зрители видели в Цезаре узурпатора, в Бруте - защитника народовластия и свободы, а Марка Антония воспринимали как ловкого демагога, подстрекателя толпы и истинного предателя, врага ценностей и устремлений римского народа.

В соответствии со своим дореволюционными представлениями артисты Малого театра стремились выделить в трагедии прежде всего моральноэтические проблемы, всячески подчеркивая вечные «классицистические» истины красоты, добра и правды. С этой точки зрения их больше волновали не те республиканские идеи народного блага, что двигали Брутом, когда он занес свой кинжал над другом - Цезарем, а сам факт измены дружбе и долгу.

Публика же желала не раскрытия индивидуальных характеров или буржуазной, мещанской, семейной драмы в декорациях героического, но изображения коллективного торжественного позитивного действия (т. е. повторения переживаний революции). Историческое прошлое и артистизм прошлого казались пошлыми и полными пассивности перед лицом неразрешенных проблем. Пожалуй, наиболее удачно это настроение, разделяемое не только отечественной публикой того времени, но и самими артистами, смутно желавшими новых способов самовыражения, выразил известный актер А. А. Остужев (1874-1953): «Я больше не понимаю пассивного, молчаливого героизма эллина Сократа. Зачем молчаливо пить цикуту, когда можно вдребезги разбить чашу, наполненную ею, и отстоять правоту своих убеждений в борьбе, в бою. Нет в арсенале моральных ценностей человека ничего более высокопробного, чем мужество, проявленное в борьбе за исторически справедливые, прогрессивные идеалы» (Остужев, 1937; цит. по: Остужев, 1956: 528).

\section{«РЕНЕССАНСНЫЙ» ШЕКСПИР: ОСНОВЫ}

Одним из ответов на такой запрос эпохи стала своеобразная и сложносоставная концепция «ренессансного» Шекспира, разработанная советскими властителями дум из самых разных областей - от А. В. Луначарского и 
И. В. Сталина до А. А. Аникста и Л. Е. Пинского - и основанная на специфическом, советском понимании историзма. В ее основе - тесное переплетение трех мотивов, которые мы обозначим как «феодализм», «демократизм» / «народность» и «веселость».

Отметим, что существование этой концепции не было четко отрефлексировано наукой и обществом: для советского человека не существовало особого, советского официально одобренного шекспироведческой наукой взгляда на Шекспира, который можно было бы назвать «ренессансный Шекспир»; речь шла лишь о «правильном» применении методологии исторического материализма. Поэтому представители и сторонники применения этой концепции не декларируют себя в качестве таковых, и их можно узнать лишь по ключевым темам: вниманию к вышеупомянутым мотивам и упору на классический историзм, понимаемый по-разному.

Следует также сказать, что, несмотря на предпринимаемые определенные усилия, эта концепция не получила широкого хождения за пределами Советского Союза, да и внутри него она со временем, к началу 1960-х гг., выродилась в нечто совершенно иное; хотя некоторые советские шекспироведы лелеяли надежду, что эта концепция станет общепринятой. Например, в конце 1950-х А. А. Аникст отмечал влияние советского шекспироведения на мировую науку, указывая, что «этическая сторона произведений Шекспира в современной (зарубежной. - $A$. $K$.) критике рассматривается в соответствии с взглядами и понятиями, характерными для общественной нравственности эпохи Возрождения» (Аникст, 1959: 8). Однако то, что воспринималось им как свершившийся факт, на деле оказалось лишь временной и малозаметной флуктуацией в мировом шекспироведении.

В западной науке в принципе не приняты представление о Шекспире как о «гении Возрождения» и акцент на эпохе Ренессанса в его творчестве, поскольку в действительности (см. хотя бы даты жизни драматурга) он является переходной фигурой, более близкой европейскому барокко. В английском же литературоведении периодизация вообще идет не по литературным / эстетическим направлениям, а по историческим: Шекспир принадлежит эпохе елизаветинского театра, а более поздние литературные периоды соответствуют датам правления отдельных монархов и т. п. (см., например, учебные пособия для студентов, составленные Алоком Ядавом, исследователем из университета Джорджа Мейсона; Yadav: Электронный ресурс).

\section{«РЕНЕССАНСНЫЙ» ШЕКСПИР: ПОЛОЖЕНИЕ ДО РЕВОЛЮЦИИ}

Прежде чем обратиться к анализу концепции «ренессансного» Шекспира, стоит немного остановиться на ее возможных дореволюционных истоках. Поскольку концепция начала формироваться в середине 1920-х гг., воз- 
можно предположить, что создавали ее люди, личностно сформировавшиеся в предреволюционные годы. Сразу оговорим, что в рамках одной статьи нет возможности подробно останавливаться на всех нюансах театральной сцены и литературных направлений в России XIX в. Нас интересует лишь то, каким образом дореволюционная русская эстетика могла помочь сформировать «советского» Шекспира.

Отметим также, что на русской сцене шекспировские персонажи показывались в романтическом аспекте и вообще «вся линия постановок Шекспира вместе с постановками Шиллера, Лопе де Вега, Гюго именовалась романтической» (Штейн, 1980: 258). При этом большинство режиссеров и актеров ощущали определенный и трудноуловимый зазор между романтической интерпретацией Шекспира и пьесами Гюго и Шиллера, изначально написанными в романтической эстетике, и для большинства исполнителей «гуманитарный пафос пьес Шиллера и либеральное свободолюбие романтических драм Гюго оказывались ближе... чем трагедии Шекспира» (там же: 257) ${ }^{3}$. Причиной этому, по нашему мнению, является подсознательное понимание артистами того, что персонажи Шекспира довольно плохо приспособлены для воссоздания в романтическом театре в силу принципиальной разнонаправленности замыслов драматурга и постановщиков: герои Шекспира многомерны, а романтический театр требовал фокуса внимания на какой-то их одной стороне. Эта проблема вполне осознавалась теоретиками романтической эстетики. Еще А. С. Пушкин писал, что шекспировские образы «не суть, как у Мольера, типы такой-то страсти, такого-то порока; но существа живые, исполненные многих страстей, многих пороков...» (Пушкин, 1962: 210). Г. В.Ф. Гегель в своей «Эстетике» отмечал характерную для современного ему театра тенденцию к раздроблению шекспировских образов, противоречащую эстетическим принципам драматурга (Штейн, 1980: 288-289). На дореволюционной русской сцене проблема эта так и не была до конца решена.

Однако настольным пособием русских любителей театра и Шекспира в XIX в. была не «Эстетика» Гегеля или «Table-talk» Пушкина, а четырехтомник «Шекспир» (1849-1850, рус. пер. 1877) немецкого историка литературы Г. Г. Гервинуса (Georg Gottfried Gervinus; 1805-1871), крайне популярного и в Европе. Представитель позднеромантической критики, Гервинус считал, что «во всех шекспировых трагедиях предметом служит коренной переворот, происходящий в более или менее благородной натуре вследствие перевеса над нею какой-либо великой страсти...» (Гервинус, 1877: 412). Конфликты шекспировских пьес объявлялись Гервинусом воплощением «вечных» и

\footnotetext{
${ }^{3}$ В цитируемом тексте речь идет о Малом театре, но подобные настроения среди артистов были широко распространены и за его пределами.
} 
«неизменных» противоречий человеческой души. Истоком трагедии героя оказывалось нарушение внутренней гармонии его личности. Таким образом, «Макбет» превращался в трагедию честолюбия, «Отелло» — в трагедию ревности, а «Гамлет» - в трагедию рефлексии. По Гервинусу, шекспировские герои всегда сами оказывались виноваты в произошедшем с ними, поскольку не исповедовали буржуазный идеал умеренности, что и приводило к их конфликту с обществом, которому они не могли противостоять: например, Отелло и Дездемона погибли потому, что оказались не способны сохранить мир в собственной семье и т. п. (см.: Там же: 45-46).

Позднее, советская критика именно в этом видела главную причину несовершенства дореволюционных интерпретаций Шекспира, ведь «из созданий великого драматурга изымалась их основа - широкая социальноисторическая проблематика» (Зингерман, 1959: 368; в данном случае и сам Б. И. Зингерман является примером такого критика). При этом определенные возражения против идеалистической концепции Гервинуса можно найти уже в протосоветской дореволюционной критике. Например, Н. Г. Чернышевский вполне верно указывал в своей диссертации, что если принять подобные интерпретации за истину, то можно начать «обвинять всех: Дездемона виновата тем, что была невинна душою и, следовательно, не могла предвидеть клеветы; Ромео и Джульетта виноваты тем, что любят друг друга. Мысль видеть в каждом погибающем виноватого - мысль натянутая и жестокая» (Чернышевский, 1949: 29). Используемое Гервинусом соединение трагического героя и жертвы воедино имеет своим результатом обеднение и ослабление самого мотива трагического в шекспировских пьесах, а последние опошляет и иногда превращает в практически бытовые конфликты (по Гервинусу, «Отелло» оказывается семейной драмой; Гервинус, 1877: 453-454), достигая, таком образом, эффекта, противоположного желаниям этого критика романтического направления.

Другим важным источником вдохновения для русской сцены XIX в. была, разумеется, сцена европейская, в первую очередь - итальянская. Движение Рисорджименто нашло живой отклик в сердцах русской публики, окружая трагико-героическим ореолом итальянских артистов, игравших шекспировские трагедии. Особенно популярны в среде театралов были Эрнесто Росси (Ernesto Rossi; 1827-1896) и Томмазо Сальвини (Tommaso Salvini; 1829-1915), неоднократно приезжавшие в Россию на гастроли. Подобно Гервинусу, они (в особенности Росси) изображали шекспировское действо как вневременное, лишенное конкретной социоисторической привязки, а у шекспировских героев акцентировали лишь те вечные человеческие черты, что были важны для драматического действия (ревность Отелло, властолюбие 
Макбета и т. п.) и, в конечном счете, служили образцами для подражания для актеров из российских театров.

Впрочем, сложившаяся в русской культуре ситуация кризиса воплощения шекспировских пьес в романтической эстетике не была уникальна. Другие европейские традиции также испытывали затруднения, разрешившиеся лишь в 20-х годах XX в. Вот что писал по поводу венгерского театра для «Театрального Октября» критик И. О. Матейка (тж. Янош Матейка / János Mathejka, Matejka; 1895-1940): «Под влиянием пьес Дюма, Сарду и Пальерона венгерская сцена обогатилась высокопарными романтическими драмами. Из скрещенья шекспировской формы с духом французской романтики возникли патетические драмы, написанные ямбом, в которых историческая среда служила только декорацией для лирических излияний драматурга. Это направление не создало ничего замечательного или жизнеспособного» (Матейка, 1926: 141). Большинство авторов «Театрального Октября» и других деятелей культуры СССР 1920-1930-х годов вполне согласилось бы с таким выводом.

\section{«РЕНЕССАНСНЫЙ» ШЕКСПИР: ПРЕДРЕВОЛЮЦИОННЫЙ КРИЗИС ВОПЛОЩЕНИЯ}

Однако, как уже отмечалось, подобные романтические интерпретации Шекспира не устраивали некоторую часть артистов, критиков и театральной публики. Они пытались переформатировать общественное представление о «правильном» способе постановки шекспировских пьес.

Известны случаи принципиального разрыва с устоявшимися (и ожидаемыми публикой) интерпретациями. Так, Г. Н. Федотова, играя Катарину в «Укрощении строптивой» (1871), смягчала традиционную гервинусовскую трактовку Катарины как капризного полуребенка в пользу более зрелой и сумасбродной девушки.

Были попытки ставить шекспировские спектакли в духе новомодных символистских драм. В качестве примера можно назвать «Кориолана», поставленного А. П. Ленским в Малом театре в 1901 г. А. Л. Штейн отмечает, что «рецензенты, писавшие о “Кориолане", вспоминали мысли Ницше о “сверхчеловеке”, ибсеновского “Доктора Стокмана”, философию Габриеля Д’Аннунцио. Спектакль вмешивался в спор о герое и толпе, гордом индивидуалисте и безликой массе», однако рецепция была смешанной, поскольку некоторые рецензенты считали, «что, поставив “Кориолана”, Ленский создал спектакль, “прямо расходящийся с указаниями самого Шекспира”» (Штейн, 1981: 124). Подобная рецепция крайне любопытна, ведь, по сути, символистская драма являлась органичным продолжением романтической эстетики, развитием ее определенных черт. Из этого примера видно, что публика дей- 
ствительно желала смены театральной парадигмы воплощения шекспировских спектаклей.

И, наконец, были попытки самостоятельного обращения к историзму, без посредничества Гервинуса. Например, при подготовке к роли леди Макбет в 1890 г. Г. Н. Федотова консультировалась с одним из основателей русской физиологической школы И. М. Сеченовым (1829-1905) по поводу психического состояния шекспировской героини (Штейн, 1980: 287). Перед нами - яркий контраст между способами подготовки актера к роли середины и конца XIX в. Если раньше считалось разумным и полезным обращаться к иностранному авторитету, литературному критику, то теперь артист хотел не иллюстрировать на сцене чужие и непригодные концепции, не изображать персонажа, каким его себе мог бы представить читатель, зритель или критик, но показать на подмостках театра живого человека во всей его сложности, личность, укорененную в реальности, добиться чего можно было лишь при привлечении внетеатрального инструментария, в первую очередь исторических и точных наук. Это желание новой точности изображения позднее, после революции, стало одним из источников социалистического реализма в литературе и на сцене.

Артисты и режиссеры и сами пытались мыслить «исторически». Например, А. П. Ленский, рассуждая о несходстве двух Фальстафов, Фальстафе хроник и «Виндзорских насмешниц» - предлагает для объяснения этой проблемы исторический, а не эстетический аргумент: комедия написана по прямому приказу Елизаветы, которой нужен был именно такой Фальстаф (Штейн, 1980: 277). Отметим, что современная шекспироведческая наука подтверждает догадку Ленского: Фальстафу присущи некоторые черты публичного образа сэра Джона Олдкасла (Sir John Oldcastle; ум. в 1417 г.), предводителя лоллардского восстания. Для современников драматурга аллегорическая связь между ними не была секретом (подробнее см.: McNabb, 2016), как и то, что Шекспир при помощи Фальстафа пародирует личность и биографию рыцаря, являвшегося политическим противником династии Тюдоров, оппозиция которого их правлению могла бы объяснить желание Елизаветы унизить мертвого врага, сделав его прообраз игрушкой в руках женщин в рамках написанной Шекспиром комедии.

Однако наиболее ярко разрыв с предшествующей театральной традицией проявился в творчестве великого русского режиссера К. С. Станиславского (1863-1938). Известен его план неосуществленной постановки «Отелло» для МХАТ (1928), во многом основанный на переосмысленном Станиславским опыте работы над предыдущей постановкой «Отелло», выполненной им в 1896 г. И хотя план этот стал известен широкой публике лишь после смерти режиссера, в 1945 г., многие исследователи, в том 
числе Б. И. Зингерман, считали, что «основные принципы сценического истолкования Шекспира, сформулированные в режиссерском плане “Отелло”... уже в середине 30-х годов - восторжествовали в советском театре. Теперьто мы понимаем, что режиссерский план “Отелло”... был грандиозным прологом к той борьбе за шекспировское наследие, которая завязалась в советском театре 30-х годов, прологом, в котором уже заключены были все в дальнейшем развитые идеи и темы» (Зингерман, 1959: 396).

К. С. Станиславский не раз выражал свое отвращение к Г. Г. Гервинусу и его концепции, даже называл его «врагом Шекспира». Причиной подобного отношения было, как и у прочих артистов, филистерское истолкование литературоведом гегелевского понимания трагического, благодаря которому смерть Отелло, случившаяся из-за его страстной, «африканской» натуры (отметим неприкрытый расизм романтической критики), оборачивается искуплением, принесенным тени умершего от горести отца, и предостерегающим от самовольного нарушения мира чужой семьи, пророчащим погибель преступившим законы «общепринятой» буржуазной морали. Как отметил Б. И. Зингерман (см.: Зингерман, 1959: 391), в письме французскому драматургу Л. Бенару (Lucien Besnard; 1872-1955) от 20 июля 1897 г. мнению Гервинуса Станиславский противопоставляет слова самого Шекспира: «...с одной стороны, у нас есть какие-то неизвестно кем придуманные традиции, а с другой - гениальные слова самого Шекспира о драматическом искусстве (Станиславский здесь имеет в виду монолог Гамлета в сцене с актерами Б. 3.). Кому верить: ученым Гервинусам и компании или самому Вильяму? Как хотите, но я верю последнему и убежденно говорю: все традиции, не сходные со словами самого гения, - глупости, и надо поскорее о них забыть» (Станиславский, 1960: 115).

В соответствии с высказанной выше позицией, очевидно сформировавшейся еще до революции, К. С. Станиславский и строит свою постановку «Отелло» 1896 г. Он отказывается видеть причины поведения Отелло в его африканской крови и, напротив, показывает конфликт трагедии как обусловленный общественными причинами, уделяет большое внимание переполоху, поднятому Яго и Родриго у дома Брабанцио, дает социальный контекст сцен в Сенате и на Кипре и т. п. Режиссер пытался показать образы Шекспира динамически, используя социальные и исторические обстоятельства для объяснения изображаемых на сцене характеров и поступков, отрицая, тем самым, классическую театральную традицию, идущую еще с античности, по которой все условия для трагедии видны и предопределены в тексте / действии заранее. Но не нужно рассматривать интерес Станиславского к контексту происходящего на сцене как уменьшение, принижение роли персонажей. Доказы- 
вая историческую обусловленность конфликта, режиссер раскрывает гуманистический замысел Шекспира (Зингерман, 1959: 374).

В том же письме Л. Бенару К. С. Станиславский пишет: «Шекспир... во всякой своей пьесе увлекался характерностью роли, но благодаря своему сверхъестественному таланту он настолько ярко обрисовывал своих героев, что они получали значение общечеловеческое. Если Островского в наше время называют бытописателем, то Шекспир был таковым в свое время» (Станиславский, 1960: 115). Т. е. в основе шекспировских пьес лежит реалистически понимаемый интерес к человеку во всех его проявлениях, для полноценного изображения которых необходимо привлекать исторический контекст; который впоследствии можно использовать для правильного воспроизведения пьесы на сцене (отметим также выбор фигуры А. Н. Островского, которого часто называют «русским Шекспиром»; см., например: Тростников, 2003). А значит, говорит советская критика в лице Б. И. Зингермана, в борьбе с ложными идеалистическими интерпретациями, видевшими в персонажах Шекспира обычных людей в исключительных обстоятельствах, нужно фокусировать внимание зрителя на исторических и социальных обстоятельствах шекспировских пьес, которые и порождают конфликт, действие; нужно видеть в персонажах Шекспира исключительных личностей в исторически обусловленных обстоятельствах.

Однако сам К. С. Станиславский не смог полностью соответствовать вышеозначенной концепции (а точнее советской интерпретации его точки зрения), довести ее до логического конца. Б. И. Зингерман прекрасно сформулировал: «Показывая обусловленность трагедии Отелло общественными противоречиями эпохи Возрождения, вводя ее в круг широкой гуманистической проблематики, Станиславский одновременно лишал образ героя черт исключительности» (Зингерман, 1959: 389). Здесь советская критика в своем понимании историзма во многом сходится с романтической, герои Шекспира - исключительны ${ }^{4}$ (в советском литературоведении было даже популярное клише о «титанах Возрождения»). Станиславский же отказывается видеть эту исключительность даже там, где она очевидна (как, например, в случае с добровольным браком между африканцем и дочкой сенатора - неслыханное дело для Венеции!) и рассматривает выдающееся своеобразие шекспировских образов через призму своей борьбы с идеалистической театральной традицией. И потому, с одной стороны, предостерегает своих учеников от изображения человека «вообще», от «вечного» человека Росси и Сальвини, а с

${ }^{4}$ По Б. И. Зингерману, «исключительность» (понимаемая как эстетический термин) персонажей Шекспира проявляется в том, что «они противопоставляют свою волю другим людям и осуществляют свои желания, подавляя желания других людей» (Зингерман, 1959: 394). 
другой - отказывает Отелло, Яго и т. д. в уникальности, делает их обычными людьми.

В этом проявляется глубинная связь К. С. Станиславского с общей традицией русского театра в ее «чеховском» ${ }^{5}$ изводе (хотя на момент постановки «Отелло» была написана только «Чайка», многие исследователи отмечают «чеховскую» трактовку образа Отелло у Станиславского, который позднее стал главным постановщиком Чехова в дореволюционной России). Необходимо особо отметить «чеховский» способ интерпретации шекспировских пьес, являющийся, по сути, примордиальной интерпретационной концепцией русской культуры ${ }^{6}$. Он будет иметь большое значение в дальнейшем. Добавим также, что Станиславский и русская культура вовсе не были одиноки в подобной трактовке: к примеру, известный английский писатель и художник Уиндем Льюис (Percy Wyndham Lewis; 1882-1957) в своем сборнике эссе о шекспировских персонажах «Лев и лис» также описывает некоторых персонажей, в частности, Яго, как обычных (например, он указывает, что театральная традиция интерпретации Яго как злобного гения интриг лишена оснований по тексту пьесы, т. к. Яго рассказывает о своем плане всем встречным, кроме, собственно, избранной жертвы; см.: Lewis, 1927: 192-194).

Подспудное влияние русской культуры вообще и репертуара русских театров в частности на интерпретации шекспировских произведений проявлялось не только в желании воссоздания на сцене «чеховского» социоисторического контекста, но и в как бы случайном (но тайно желанным публикой) «чеховском» смешении трагического и комического, послужившего основным источником уже упомянутого мотива веселости Возрождения (об этом - в следующей части). А. Л. Штейн отмечает особый «комедийный реализм», присущий артистам Малого театра, говоря, что они «демонстрировали в пьесах Шекспира искусство играть классическую комедию, которому они научились, играя комедии Мольера, Гоголя, Островского. Это было умение лепить выпуклые характеры, внутренняя свобода и юмор, непринужденность и легкость произнесения реплик и монологов» (Штейн, 1980: 272). Приведем лишь два известных примера: комедийная интерпретация И. В. Самариным (1817-1885) образа Меркуцио (жизнерадостен, умирает с

\footnotetext{
${ }^{5}$ Под «чеховской» традицией русского театра мы, вслед за советской критикой, подразумеваем творческий интерес драматургов, режиссеров и актеров к изображению объективных связей между судьбой отдельного человека и обществом.

6 Заметим, что в таком способе интерпретации таится важная подсказка, раскрывающая суть взаимоотношений текста и интерпретатора: последний по-прежнему идет «от себя», а не «от текста». Это говорит о том, что в подобном способе интерпретации нет ничего специфически шекспировского (т. е. что исходный текст не влияет на свою трактовку); великий драматург и его произведения выступают здесь лишь как материал для создания в русской культуре своего национального образа.
} 
шуткой и улыбкой на устах и т. п.), как будто взятая им ранних шекспировских комедий («Сон в летнюю ночь» и т. д.; позднее Самарин использовал полученный опыт в снискавших ему славу комических ролях), и игра П. М. Садовского - старшего (1818-1872), блиставшего в комедийных ролях могильщика в «Гамлете» и шута в «Короле Лире», а затем решившего сыграть и самого Лира, правда, уже без особого успеха (образ получился слишком будничным для зрителя). Отметим, что хотя статья Штейна фокусируется на Малом театре, ситуация в других академических театрах Российской империи не слишком отличалась от описываемой им.

Позднее, в послереволюционные годы, представление о необходимости исторического взгляда на шекспировские пьесы стало восприниматься настолько естественно, что, например, великий русский актер А. И. Южин (1857-1927), заставший обе эпохи, обсуждая свою подготовку к роли Ричарда III (1922, Малый театр), говорил: «Я, конечно, буду играть шекспировского, а не исторического Ричарда, но думаю, что с историческим освещением его личности и историческим материалом нельзя не считаться» («Новости сезона» от 30 августа 1897 г.; цит. по: Штейн, 1980: 281). Ричард Южина сочетал в себе романтический демонизм, присущий традиционным трактовкам в духе XIX в., с макиавеллистской социоисторической проблематикой феодальной борьбы за власть. Такая трактовка образа стала канонической и продержалась до окончания самой концепции «ренессансного» Шекспира, т. е. до начала 1960-х гг.

\section{СПИСОК ЛИТЕРАТУРЫ}

Аникст, А. А. (1959) Шекспир - народный писатель // Шекспировский сборник 1958. М. : Всероссийское театральное общество. 604 с. С. 7-44.

Верней, Э. (1926) Рабочий театр в Англии // Театральный Октябрь : сб. № 1. Л. ; М. 182 с. С. 121-126.

Гервинус, Г. (1877) Шекспир : в 4 т. Изд. 2-е, доп. СПб. : Изд. книгопродавца Д. Ф. Федорова. Т. 4. 473, [3] с.

Герцог, В. (1926) Театр в современной Германии // Театральный Октябрь : сб. № 1. Л. ; М. 182 с. С. 127-137.

Захаров, Н. В., Луков, Вл. А. (2009) Бартошевич Алексей Вадимович [Электронный ресурс] // Электронная энциклопедия «Мир Шекспира». URL: http://www.world-shake.ru/ru/Encyclopaedia/3749.html [архивировано в WaybackMachine] (дата обращения: 27.11.2017).

Зингерман, Б. И. (1959) Анализ режиссерского плана «Отелло» К. Станиславского // Шекспировский сборник 1958. М. : Всероссийское театральное общество. 604 с. С. 364-396. 
Марков, П. А. (1967) Театральный Октябрь // Театральная энциклопедия : [в 6 т.] / гл. ред. П. А. Марков. М. : Советская энциклопедия. Т. 5: Табакова - Яшугин. 1136 стб. Стб. 159.

Матейка, И. (1926) О венгерском театре // Театральный Октябрь : сб. № 1. Л. ; М. 182 с. С. 139-151.

Мокульский, С. С. (1926) Переоценка традиции // Театральный Октябрь : сб. № 1. Л. ; М. 182 с. С. 9-29.

Остужев, А. А. (1937) Мысли о героическом // Советское искусство. 17 января.

Остужев, А. А. (1956) Мысли о героическом // Ежегодник Малого театра. 1953-1954 / отв. ред. М. И. Царев ; науч. ред. А. П. Клинчин. М. : Искусство. 714 с. С. $525-528$.

Пушкин, А. С. (1962) Table-Talk // Пушкин А. С. Собр. соч. : в 10 т. М. : ГИХЛ. Т. 7: История Пугачева ; Исторические статьи и материалы ; Воспоминания и дневники. 463 с. С. 206-222.

Станиславский, К. С. (1960) Полн. собр. соч. : в 8 т. М. : Искусство. Т. 7: Письма. 1886-1917. 811 с.

Тростников, В. Н. (2003) Русский Шекспир: 180 лет со дня рождения. Александра Николаевича Островского // Русский дом. № 4. С. 14-15.

Ходорковская, Л. С., Клинчин, А. П. (1959) А. А. Остужев - актер Шекспира // Шекспировский сборник 1958. М. : Всероссийское театральное общество. 604 с. С. 313-363.

Чернышевский, Н. Г. (1949) Эстетические отношения искусства к действительности : диссертация // Чернышевский Н. Г. Полн. собр. соч. : в 15 т. М. : Гослитиздат. Т. 2 : Статьи и рецензии. 1853-1855. 943 с. С. 5-92.

Штейн, А. Л. (1980) Малый театр играет Шекспира... Статья первая // Шекспировские чтения 1977. М. : Наука. 319 с. С. 257-289.

Штейн, А. Л. (1981) Малый театр играет Шекспира (статья вторая) // Шекспировские чтения 1978. М. : Наука. 326 с. С. 121-149.

Lewis, W. (1927) The lion and the fox: The role of the hero in the plays of Shakespeare. L. : Grant Richards Ltd. 326 p.

McNabb, C. H. (2016) Shakespeare's semiotics and the problem of Falstaff // Studies in Philology. Vol. 113. No. 2. Spring. P. 337-357.

Yadav, A. Historical outline of Restoration and 18th-century British literature [Электронный pecypc] // George Mason University. URL: http://mason.gmu. edu/ ayadav/historical\%20outline/overview.htm [архивировано в WaybackMachine] (дата обращения: 27.11.2017).

Дата поступления: 30.11.2017 2. 
Кузьмичев Арсений Игоревич - младший научный сотрудник отдела литературоведения Института научной информации по общественным наукам Российской академии наук. Адрес: 117997, Россия, г. Москва, Нахимовский пр-т, д. 51/21. Тел.: +7 (499) 128-88-81. Эл. адрес: kusmicheff@yandex.ru

Kuzmichev Arseniy Igorevich, Junior Researcher, Department of Literary Studies, Institute of Scientific Information on Social Sciences (INION), Russian Academy of Sciences. Postal address: 51/21 Nakhimovskii Ave., 117997 Moscow, Russian Federation. Tel.: +7 (499) 128-88-81. E-mail: kusmicheff@yandex.ru

\section{Для цุитирования:}

Кузьмичев А. И. Пьесы У. Шекспира в советском театре и кинематографе (по материалам «Шекспировских чтений»). Часть I. Концепция «ренессансного» Шекспира [Электронный ресурс] // Горизонты гуманитарного знания. 2017. № 6. С. 153-168. URL: http://journals.mosgu.ru/ggz/article/view/648 (дата обращения: дд.мм.гггг). DOI: 10.17805/ggz.2017.6.9 